DOI: https://doi.org/10.34069/AI/2021.46.10.6

How to Cite:

Luan, L. (2021). National and cultural elements in Russian children's discourse. Amazonia Investiga, 10(46), 71-78. https://doi.org/10.34069/AI/2021.46.10.6

\title{
National and cultural elements in Russian children's discourse
}

\section{Национально-культурные элементы в русском детском дискурсе}

Received: August 18, 2021

\begin{abstract}
The work is devoted to the topical problem of linguoculture. The subject of the research is cultural codes in children's discourse based on the materials of the living speech of Russian children on the site "Children Speak". For the research general scientific methods of analysis and generalization, descriptive and contextological methods, the method of linguoculturological and ontogenetic analysis are used. As a result, the linguocultural and linguosociological aspects of the formation of a child's linguistic personality are considered. At the same time, attention is focused on identifying the peculiarities of Russian children's discourse in the linguocultural aspect, studying the ethnocultural determinants of creating the linguistic personality of children. Based on the results of the analysis, it was concluded that the national culture is one of the decisive factors affecting the speech activity of children. In the process of mastering the native language, the child simultaneously acquires a special national mentality and creates a system of values that coincides with it, such as patriotism, the symbolic meaning of animal archetypes, attitude towards the family, etc. Moreover, under the influence of a child's linguistic personality, a certain deviation from the usual national worldview is also manifested in children's discourse.
\end{abstract}

Keywords: children's discourse, cultural linguistics, linguistic personality, linguistic worldview, national mentality.

\footnotetext{
${ }^{20} \mathrm{Ph} . D$. student, RUDN University, Russia.
}

Accepted: October 27, 2021

Written by:

Luan Luan ${ }^{20}$

https://orcid.org/0000-0002-2173-2177

\begin{abstract}
Аннотация
Работа посвящена актуальной проблеме лингвокультуры. Предмет исследования культурные коды в детском дискурсе на материалах живой речи русских детей на сайте «Говорят дети». Для исследования используются общенаучные методы анализа и обобщения, описательный и контекстологический методы, метод лингвокультурологического и онтогенетического анализа. В работе предлагается комплексный подход к исследованию дискурса русскоязычных детей. В результате рассматриваются лингвокультурный и лингвосоциологический аспекты становления детской языковой личности. При этом внимание фокусируется на выявлении особенностей русского детского дискурса в лингвокультурном аспекте, изучении этнокультурных детерминантов создания языковой личности детей. По итогам анализа сделан вывод о том, что национальная культура является одним из решающих факторов, воздействующих на речевую деятельность детей. В процессе усвоения родного языка ребенок параллельно приобретает особенную национальную ментальность и создает совпадающую с ней систему ценностей, таких как патриотизм, символичное значение архетипов-животных, отношение к семье и т.д. Тем более, под влиянием детской языковой личности также проявляется некое отклонение от узуального национального мировоззрения в детском дискурсе.
\end{abstract}

Ключевые слова: детский дискурс, лингвокультурология, национальный менталитет, языковая картина мира, языковая личность. 


\section{Introduction}

The assimilation of the language plays an important role in the process of ontogenesis, it not only ensures communication, but also helps to form a system of values, a way of thinking, corresponding to the traditions of the people. In addition to the cultural content, children's discourse also reflects the linguistic personality of children, their thinking, children's worldview and other characteristics that differ from the speech of adults. Thus, the study of children's discourse can be carried out in two dimensions, horizontal and vertical. In the vertical, more precisely, chronological dimension, the study of children's discourse makes it possible to find out the process and mechanism of language acquisition, the features of children's speech production, the deviation of children's discourse from the norm and standard of the normative language. In the horizontal dimension, the study of children's discourse can be carried out within the framework of linguoculture to clarify the national and cultural elements in the consciousness and discourse of Russian children.

The relevance of the study is due to the fact that children's discourse as an important object of discourse analysis has a special research value. First, the speech production of children "makes it possible to see in dynamics those phenomena that are curtailed in the speech of an adult and are not available for observation" (Danyushina, 2014, p. 3 ). Secondly, the study of linguo-cognitive and speech-thinking activities of children makes it possible to illuminate external influencing factors on the characteristics of children's discourse.

The work examines the speech production of Russian-speaking children on the site "Children Speak" - the largest electronic version of the diary entries of parents. The characteristics and features of children's discourse are considered from the perspective of the national linguistic culture.

\section{Theoretical Framework or Literature Review}

Interest in the study of the development of children's discourse has always existed, but a systematic study of this issue has begun recently. Only in the middle of the XIX century there were scattered publications of diary entries of children's speech (Hippolyte Tenn - in the magazine "Mind", 1877, Charles Darwin, William Preyer, Clara and William Sterns, Werner Leopold, etc.). The well-known linguist I. A. Baudouin de Courtenay kept diary records of the development of the speech of his children; under the leadership of Professor Schumann in the 60 s of the XX century, a linguistic circle operated in Krakow that systematically recorded children's speech and worked with these materials (Perezhigina, 2004, p. 61).

In Russia, the psychologist N. A. Rybnikov has been trying for many years to provide psychological theoretical support to parents and teachers in raising a child. Since the beginning of the 20th century, N. A. Rybnikov studied child psychology and the mental development of a child in depth. The materials of his research were diaries of children's speech production collected by parents. When analyzing the development of children's speech, N. A. Rybnikov (1926) put forward the characteristics of the age characteristics of the child.

Researcher S. N. Tseitlin in his work puts forward two aspects of the study of children's discourse:

1) from the position of comparing the language system of the adult language. From this point of view, children's discourse can be viewed as "a kind of "immature" adult language, replete with inaccuracies, innovations, etc." (Tseitlin, 2004, p. 275-278);

2) from the perspective of the child's language system itself, which has its own units, categories and structures of language. From this point of view, children's discourse can be viewed as "the level of the child's cognitive development achieved by a certain moment and capable of satisfying his immediate communicative needs" (Tseitlin, 2004, p. 275-278).

The relationship between the early speech development of a child and society has also aroused common interest among linguists. A well-known representative of this theory is the outstanding Russian scientist L. S. Vygotsky, who was the first to talk about the fact that a child's speech development is influenced by a social factor, including collective activity. In other words, in different age periods there is a special and peculiar social circumstance for children, in which the corresponding relationship of the child with the environment is built. Society makes demands on the child that he does not yet meet. And in order to be understood, adaptation to these requirements is necessary (Vygotsky, 1997). 


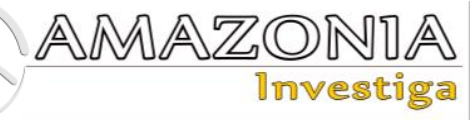

The sociocultural environment differs not only by the ethnic community, but also by the different subcultures of a particular people. Thus, it influences discourse from two directions and results in multilingual discourses, discourse of different types. In this regard, it is necessary to study children's speech, taking into account the socio-cultural aspect. However, the sociocultural factor is only one of the decisive factors. As mentioned above, the psychological state, which correlates with the child's speech activity, is no less important.

Suppose that discourse can be viewed within the framework of pure linguistics, analyzing a linguistic sign in itself. However, when studying children's discourse, not only the subject of research is concretized, but also the scientific sphere, more precisely, it is necessary to take into account various sociolinguistic, linguocultural, psycholinguistic factors. Such factors in many aspects affect language and speech behavior. Children's discourse, in turn, focuses on how children use a language sign, how their speech products differ, "depending on their age, gender, social status, level and nature of education, on the level of general culture, etc." (Belikov \& Krysin, 2001, p. 3).

The semantic volume of children's discourse is wider than children's speech, which "is only a part of children's discourse, its verbal component" (Samigulina \& Danyushina, 2014, p. $35)$. And under children's discourse, in addition to the verbal products of children (children's speech), such non-verbal components as ethnoculture, mentality, picture of the world, the degree of development of thinking, education, etc. are also understood. To analyze children's discourse, it is necessary to pay attention to the concept of a child's linguistic personality, which includes not only the speech production of children, but also extralinguistic factors in the processes of speech ontogenesis, perception and use of language, and cognitive development of the child.

\section{Methodology}

The research is carried out in three stages. At the first stage, it is necessary to determine the theoretical and methodological foundations for the study of children's discourse. This procedure is implemented using general scientific methods of analysis and generalization. At the second stage, speech products are selected on the material of the recording of children's speech on the site "Children Speak". The third stage includes carrying out various aspects of the analysis to identify the characteristics of the discourse of Russian children and the national and cultural elements in it. At this stage, a number of methods were used, including the descriptive and contextological method, the method of linguoculturological and ontogenetic analysis.

\section{Results and Discussion}

When studying discourse in the linguocultural sphere, "it is necessary to take into account the socio-psychological and national-cultural conditions" (Kolosova, 2010, p. 96). While on the other hand, a person can be "viewed through the prism of his speech and is characterized in cognitive, social, psychological and cultural terms" (Mikhaylova, 2019, p. 132). The children's discourse contains national and cultural elements that influence the linguistic picture of the world of children. First of all, a sense of national identity and patriotism are revealed. On the one hand, this is due to natural manifestations under the influence of the environment. On the other hand, it has to do with patriotic education, which is closely related to teaching the native language.

In the example We do not live in Europe, but in Russia, with a narrowing of the semantic scope of the concept "Europe", a child, accordingly, expands the geographic coverage of Russia. In this statement, you can see the importance of the "Russia" label for the child. Children's speech production Mom, why do we live in Russia and not in Moscow? shows that Moscow is a significant and irreplaceable place that symbolizes Russia. Patriotism and a sense of national pride are reflected in such statements of children as: There are two lands, ours and the American; Russia is more than everything; Russia without end and edge! When I grow up, I will become a military man and will protect my mother, father, Ira, granny and Russia, but I don't know where this Russia is. The last example shows that a young child may not yet know where Russia is, what kind of Russia is, but is already establishing a connection between himself and Russia, he even has a desire to protect it. It really is the impact of the national culture on the mentality of children.

In addition to the attitude towards the homeland, the perception of family relations is also one of the most important components of the national culture. "Social interaction as a phenomenon of language and culture developed on the foundation of tribal relations and pagan animation of natural and cosmic forces" 
(Vladimirova, 2018, p. 187). Thus, in the linguocultural dictionary the concept of "family" is included as an important unit of the Russian linguistic picture of the world (Stepanov, 1997). Moreover, the family, as a part of the social system, plays a significant role in the upbringing of future generations and the spread of the native language, national culture, value system, rules of behavior and other spiritual elements. We can say that national linguistic culture and family philosophy are interconnected.

Children's speech materials show that children occupy the main place in Russian family relations, for example, I will be a tiger, and you will be a loaf ... In general, you yourself choose what kind of meat you will be; If I knew that I would have such a sister, I would not have been born! Mom, I think it's time for us to teach Dad to sleep on our own; Mom, dad and I will go (to the store) together. Okay? We have a male conversation there! You and I will go there tomorrow, we also need to talk about something; Can I be the head of the family when my grandmother leaves? In general, a husband and wife do not become a family until they have a child. It's the child that connects them. From the examples above, it is clear that children, to a certain extent, place themselves at the center of attention in the family and allow speech on many topics.

As T. E. Vladimirova says, "peculiar mental worlds are the result of an integral interaction of universal, that is, common to all or for most of the languages, and culturally specific features of national linguistic personalities" (Vladimirova, 2021, p. 41). The concept of "faith", which does not have equivalent words in other languages, is primarily attributed to the special Russian national and cultural features. Accordingly, the Bible, as the main spiritual book of the Russian people, influences the comprehensive mentality of Russians, including Russian family relations, and the attitude of parents towards children. So, in the Bible there is such a dogma: "Children are indeed a heritage from the LORD, and the fruit of the womb is His reward" (Psalm 127: 3). In Russian linguoculture, there are also such proverbs as "A family without children, like a flower is odorless" (Boychuk, 2015), "Whoever has no children lives in sin (so that God forgives, they take a foster child)" (Dal, 1989, p. 333). In Soviet times, there were slogans: "Devote the best to children!", "All the best - to children!" These speech products prove the vital importance of children in family relations in Russian culture.
When studying the statistical data in the Russian associative dictionary at the request of the word "family", we see that among all the reaction words in the semantic category "family member", the word "children (child)" occupies the greatest share - it was mentioned 37 times. From this it can be clearly seen that even after the transition from the traditional model of the family to the modern model, children still constitute the core of the Russian family.

In the course of the study of Russian family relations, it is observed that in communicative activity, children often talk about death, even often with elders. This not only reflects the open attitude of children towards death, but also confirms the thesis of loose subordination in relations between generations. For example, a boy said to his dad: When you get old and die ... I'll take your drill!; a boy to his mother: When I grow up, I'll buy one for myself! ... you will already be dead by that time; a girl to an older sister: If you die, I will get myself a new sister, don't worry; boy to grandfather: Here you are, grandfather will soon die, and I will follow the coffin and creak; child - to grandmother: But when you, grandma, die ... (grandmother is in shock), the child continues: Well, you are not going to live like a crow for three hundred years! There are also such dialogues between children and adults: - Will you die too? - Yes. - Do you want? - No. - But you will have to; - Grandma, are you going to die? - I'll die. - That's when I'll turn your sewing machine! From these statements it is clear that, firstly, the theme of death does not arise by chance, it is touched upon in the speech activity of many children; secondly, conversations about death often arise between children and adults in the family, and it is noticeable that children can tell any older relative about death; and thirdly, Russian children do not avoid mentioning death and consider it a natural law of the world.

The reasons for the birth of such speech products and moral values lie in the national culture and the influence of religion, for example, "one's day of death is better than his day of birth" (Ecclesiastes 7: 1); God will "shine on those who live in darkness and in the shadow of death, to guide our feet into the path of peace" (Luke 1: 79); "those who are considered worthy to share in the age to come and in the resurrection from the dead $<\ldots>$ can no longer die, because they are like the angels" (Luke 20: 35-36). There are many similar religious teachings about death, but it is already possible to understand that the Orthodox believe that after death people will receive new life and will live with God forever. 


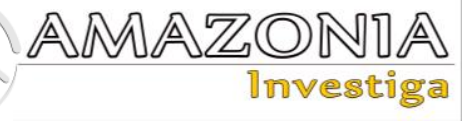

In this regard, the Russians, under the influence of the Bible, to a certain extent, are more relaxed about death. Accordingly, such a mentality enters the minds of Russian children and is reflected in their discourse.

Religion is an integral part of the national culture. Its role is manifested in the spiritual activity of the people. Religion exerts its influence on all aspects of Russian life. At a certain level, religion is invisible and immaterial. As such, it is relatively difficult for children in the early cognitive stage to understand some of the religious elements. Sometimes a child understands a certain natural phenomenon as a magical power. This way of learning about the world by children is similar to how people understand the world at an early stage of social development. At the same time, it can be concluded that a person, regardless of the age factor, with limited knowledge often explains an unfamiliar phenomenon with the help of an unknown force. And, accordingly, in Russian children's mind, religious elements often serve as such a force. So, there are such typical examples from children's speech production: Mom, is there a bus number 666? Devil's bus? Earthquake - is it God knocking on us?

"The uniqueness of the verbal reflection of the world is predetermined both by the peculiarities of the national mentality and by the objective and sometimes quite obvious differences $\langle\ldots\rangle$ of the natural environment" (Kornilov, 2003, p. 147). Nature and the environment in their own way affect the way children perceive the world. Children in Russia inevitably face such natural characteristics as long winters, snow, frost, etc. Accordingly, these factors often appear in their speech production and become important components of their linguistic picture of the world. For example, a boy said that the sun does not work in winter. This opinion appears in connection with the constant cloudy weather in the winter, and, in turn, shapes the child's worldview.

Under the influence of the Russian climate, topics about winter appear in children's discourse much more often than topics about other seasons. So, the study of speech materials on the site "Children Talk" shows that entries with the marker word "winter" - 425, "summer" - 345 times, and about spring and autumn - only 105 and 94 times. These data, to a certain extent, prove the importance of winter in the life of Russians and their desire for a warm summer.
"Vocabulary is a very sensitive indicator of the culture of the people <...> Behind the same lexical form in each language can hide very different concepts that are formed in the depths of its history and culture" (Kolosova, 2010, p. 97). The special climate also gives children mixed impressions of the seasons, which may not correspond to the standard semantic word volume. In other words, the natural conditions of the environment affect the linguistic picture of the world of children. Evidence of this can be found in children's discourse, for example: Mom, I don't understand something. You recently told me that spring is when the sun is shining and warm, and everything is blooming. But somehow I feel a catch; Dad, why is it always autumn in our city? It can be clearly seen here that even the universal concept of a natural phenomenon differs in definitions in different linguocultural environments. Here are some more examples: Spring is coming? I didn't notice. Is summer coming soon? And at least there won't be ice in the summer? Mom, did you burn the effigy of winter? Why is it snowing? And why has spring come and the snow hasn't gone away yet?

The unique natural resources of Russia make it possible to expand the vocabulary of Russian children, enrich their linguistic picture of the world. For example, the weather in Russia is relatively cold, and the luce is the most suitable fish for survival at this temperature, in this regard, the luce and its name are often manifested in the communicative activities of the people, including children. This means that the concept of luce, its name and image are recorded in the Russian language and in the Russian linguistic culture. However, in some countries, one can imagine that the majority of residents, even hearing the name translated in their native language, do not know what a luce is. Such a phenomenon can be viewed as a conceptual gap (among a certain group of people or in a certain living environment). Since nature and the environment have a great influence on the formation of the linguistic personality and the linguistic picture of the world, information about the history, geography and culture of Russia is sometimes lacking in the discourse of Russian-speaking children abroad (Gavrilina, 2021).

Phraseology is one of the brightest and figurative systems of language (Piterkina, 2009), they reflect the mentality, value system, worldview, traditions of the people, etc. Thus, they are often characterized by originality, symbolism and expressiveness. "Most phraseological units by origin are frozen folk metaphors, comparisons, metonyms, parts of proverbs and sayings. The 
figurative representations expressed by these means reflect some (more often funny, negative) facts of life and everyday life, characterize a person" (Fedorov, 2008, p. 5-6). "Special properties have made proverbs so persistent and necessary in everyday life and speech. A proverb is not just a saying. It expresses the opinion of the people. It contains the people's assessment of life, observations of the people's mind" (Zhukov, 2000 , p. 6). National proverbs and idiomatic expressions have an impact on the speech activity of children from an early age, and in parallel - on their linguistic picture of the world.

Phraseological unit - lexically indivisible, stable in its composition and structure, integral in meaning, the phrase reproduced in the form of a ready-made speech unit (Telia, 1996). Since stylistic means and figurative meaning are often hidden in proverbs and phraseological units, during their perception and application, children often encounter violations. By their nature, these violations can be divided into two groups misunderstanding and non-canonical use. From these two sides we consider the reception and use of Russian proverbs and phraseological units by children.

Misunderstandings mainly arise in cases where there is a large difference between literal and actual meaning. For example, to the question: sayings related to safety, the girl replies: Do not pour oil on the fire. Obviously, the child only understands the literal meaning of the saying, and makes a connection between it and safety. A typical misunderstanding also arises when the child perceives the phraseological unit "skeleton in the closet": the boy is afraid to take things in the closet, thinking that there really is a skeleton in the closet. A similar situation is when a child considers the phrase "heals before marriage" as unsuitable for consoling a burned mother, since she is already married. The phraseologism "to get up on the left foot" in Russian has a figurative meaning of a bad mood, but children with imperfect knowledge often understand it by its literal meaning. For example, a three-year-old girl heard that she should not get up from her left foot and decided to always get up with her right foot. When she inadvertently got up from her left foot, she was very upset. Based on this, we can come to the conclusion that phraseological units from different sides influence children not only in the linguistic sphere, but also on their thinking and everyday habits. In a sense, it is these influencing factors that make up the national culture. The study of children's speech production shows that misunderstanding is reflected in the perception of such idioms as "swallowing books"; "Do not have time to look back, how ..."; "Seven times measure once cut"; "Hang your nose" and many others. This phenomenon is primarily explained by the age factor: children have limited knowledge about the meaning of expressions, their thinking abilities are still developing.

Children can understand the meaning of a proverb or phraseological unit, but make mistakes when using it. The reason is often a deviation from the normative rules of the language or the generally accepted language habits. For example, "to hit the bull's-eye" means "to do or say exactly what is needed, exactly as it should, at the right time, at the right moment" (Fedorov, 2008, p. 504), and the child uses the expression "almost bull's-eye" in the meaning of an incorrect answer. It should be noted that there is a semantic connection between the two statements, however, the original phraseological unit emphasizes accuracy and correctness, which cannot be used with the adverb "almost", which describes a vague degree. The phraseologism "to kill the worm" means "to have a snack, to satisfy your hunger slightly" (Fedorov, 2008, p. 245). This linguistic unit, perhaps, is difficult for a child to remember, and then a case appears when a boy, wanting to express a similar meaning, creates new constructions "to eat an ant". It is easy to see that these two expressions are similar to each other both in the syntactic relation and in the semantics of the lexemes used. There is a case when, upon hearing her mother's complaint "tired as a dog", the girl says I am tired as a puppy in a similar situation. Hence, it can be understood that a child at an early age perceives phraseological units as separate used linguistic units that can be disassembled and restructured. Accordingly, according to the logic "mother - dog and daughter - puppy", the child constructs a syntactic innovation.

Phraseologisms and proverbs present to children the moral values of the people, thus, with the help of the language, national culture and mentality are spread. In the Russian language there is a proverb "a soldier will not offend a child", which teaches children to be truly masculine, the need to protect the weak, philanthropy, and so on. Having heard the proverb, a child can create his own system of values while understanding its meaning. So, under the influence of the proverb, the boy says: Dad, I will no longer offend the cat. This indicates the educational role of phraseological units.

The analysis of children's discourse also shows that symbols of a vivid national character, such 


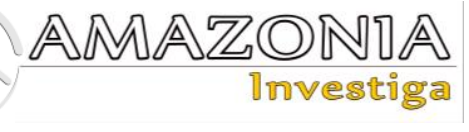

as vodka, skates, sleighs, ballet, etc., often appear in the speech production of children. Since the language is a mirror of culture, national cultural factors to one degree or another are hidden in every speech activity of the people and, in particular, of children.

\section{Conclusions}

The concept of "children's discourse", as one of the types of discourse, is also ambiguous and multifaceted, but it is presented as a broader phenomenon than children's speech and includes not only verbal, but also non-verbal components. Children's discourse focuses on how children use language signs, how their speech products differ depending on age, gender, social status, level and nature of education, from the level of general culture, etc.

The study of children's discourse allows us to analyze the features of the linguistic personality of children, their mental actions in communication. National and cultural factors influence the formation of the linguistic personality of children. In the speech of a child, who is a bearer of the characteristics of his native language and culture, his ethnicity and cultural symbols are reflected. With regard to the analysis of national and cultural factors in children's discourse, one can conclude that, first of all, children acquire patriotism and cultural identity when mastering their native language.

The study of the attitude to family, death, nature, religion in Russian linguocultures reveals a special mentality in the worldview, lifestyle, beliefs, value systems of Russian children. Children's discourse is a valuable material for analyzing the influence of national culture on the formation of a person's linguistic worldview and cognitive system.

Hidden expressions in proverbs and phraseological units show the cultural codes of Russian linguistic cultures. The study proves that in the process of mastering the language, children master national cultural codes and then become representatives of the linguistic culture of their native language.

\section{Bibliographic references}

Belikov, V. I., \& Krysin, L. P. (2001). Sociolinguistics: Textbook for universities. Moscow: Russian State University for the Humanities.

Boychuk, I. A. (March, 2015). Family is a native word! (Scenario of meeting with parents in a family club). In G. D. Akhmetova of the President of the Congress, Topical issues of modern pedagogy. VI International Scientific Conference, Ufa. URL: https://moluch.ru/conf/ped/archive/148/7430 /

Dal, V. I. (1989). Proverbs of the Russian people: collection of V. Dal in 2 volumes. Moscow: Fiction.

Danyushina, L. A. (2014). Children's discourse as a phenomenon of the emerging linguistic personality (doctoral thesis). South Federal University. Rostov-on-Don. URL: https://viewer.rusneb.ru/ru/rs101005556708? page $=1 \&$ rotate $=0 \&$ theme $=$ white

Fedorov, A. I. (2008). Phraseological dictionary of the Russian literary language: about 13000 phraseological units. Moscow: Astrel.

Gavrilina, M. A. (2021). The Speech Portrait of Russian-Speaking Schoolchildren in Latvia. Tomsk State University Journal, (462), 173180.

Kolosova, A. A. (2010). Ethnopsycholinguistic determinism of discourse. Moscow City University of Psychology and Education. Recovered from https://psyjournals.ru/files/32859/philology_ 2010_1_Kolosova.pdf

Kornilov, O. A. (2003). Linguistic pictures of the world as derivatives of national mentality. 2nd ed., Rev. and add. Moscow: CheRo.

Mikhaylova, I. S. (2019). Speech portrait at the Russian language lesson in the 8th grade of secondary school. Philological class, 2 (56), 132-137. DOI 10.26170/FK19-02-17. URL: https://cyberleninka.ru/article/n/rabota-nadrechevym-portretom-na-uroke-russkogoyazyka-v-8-klasse-sredney-shkoly/viewer

Perezhigina, N. V. (2004). Normative stages of the formation of children's speech and their qualitative features. Development of children's speech: problems of norm and pathology: Text of lectures on the course of children's neuropsychology. Yaroslavl: Yaroslav. state university. 60-91. URL: https://rusneb.ru/catalog/000199_000009_00 2714833_164182/

Piterkina, Yu. C. (2009). Phraseologisms in Children's speech. Bulletin of the Russian State Pedagogical University named after A.I. Herzen, 108, 128-133. URL: https://cyberleninka.ru/article/n/frazeologiz my-v-detskoy-rechi/viewer

Rybnikov, N. A. (1926). The language of the child. Moscow, St. Petersburg: State. publishing house. URL: https://search.rsl.ru/ru/record/01009135094

Samigulina, F. G. \& Danyushina, L. A. (2014). Children's discourse as a linguo-cognitive 
phenomenon. Rostov-on-Don: Science and Education Foundation. URL: https://search.rsl.ru/ru/record/01007898390

Stepanov, Yu. S. (1997). Constants: Dictionary of Russian Culture. Moscow: Languages of Russian culture.

Telia, V. N. (1996). Russian phraseology. Semantic, pragmatic and linguocultorological aspects. Moscow: Shkola" Languages of Russian culture.

Tseitlin, S. N. (2004). Directions and aspects of the study of children's speech. Children's speech as a subject of linguistic research. 275-279.
Vladimirova, T. E. (2018). Russian discourse in intercultural communication: Existentialontological approach. Moscow: LENAND.

Vladimirova, T. E. (2021). On the Russian mentality in language, speech and scientific discourse. Publishing house of RUDN, 39 (1), 44-51.

Vygotsky, L. S. (1997). Questions of child psychology. St. Petersburg: UNION.

Zhukov, V. P. (2000). Dictionary of Russian proverbs and sayings. 7th ed., Stereotype. Moscow: Russian language. 